\title{
The Psychological Experiences of Using Islamic Philosophy Approach among Women's with Advanced Breast Cancer in Indonesia
}

Maria Komariah $^{1 *}$, Shurouq Ghalib Qadous ${ }^{2}$ (D), Mohd Khairul Zul Hasymi Firdaus ${ }^{3}$ (D), Hana Rizmadewi Agustina ${ }^{1}$, Ati Surya Mediawati ${ }^{1}$, Henny Yulianita ${ }^{1}$, Atlastieka Praptiwi ${ }^{1}$, Dyah Setyorini ${ }^{1}$, Ryan Hara Permana ${ }^{1}$

${ }^{1}$ Department of Fundamental Nursing, Faculty of Nursing, Universitas Padjadjaran, Sumedang, West Java, Indonesia; ${ }^{2}$ Deparment of Nursing and Midwifery, Faculty of Medicine and Health Sciences, An-Najah National University, Nablus, Palestine; ${ }^{3}$ Department of Medical Surgical Nursing, Kulliyyah of Nursing, International Islamic University of Malaysia, Kuantan, Pahang, Malaysia

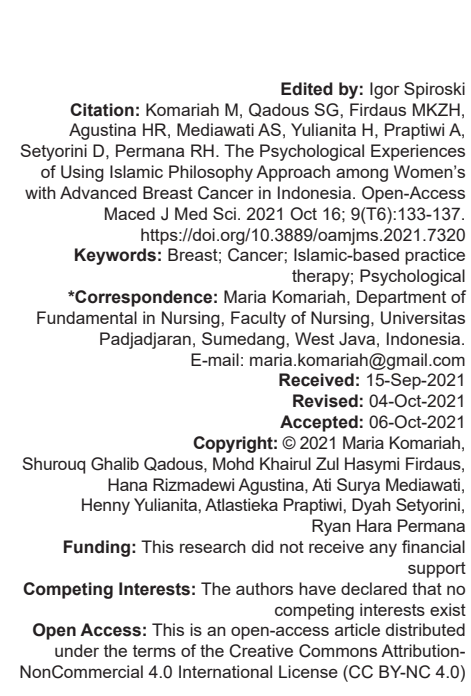

Introduction

Breast cancer has been classified as the most common causes leading to death among women. Approximately 627,000 women die due to breast cancer which constitute around $15 \%$ of cancer death rate worldwide [1]. While breast cancer rates show relatively higher rates in women living in developed countries, but in reality, breast cancer rates increase in almost every area worldwide [1].

Incidence of breast cancer tends to increase in Indonesia, and it is expected to be the highest number of cancer cases. Each year, breast cancer cases continue to rise, about 100 new cases occurred among 100,000 inhabitants [2]. As stated in the statistics from the Ministry of Health, in 2012, the prevalence of cancer is 4.3 in every 1000 people. In fact, the data previously mentioned reveal that the prevalence is one patient to
1000 people. Two kinds of cancer that frequently occur in Indonesia are breast cancer and cervical cancer. Breast cancer incidence rate is 26 out of 100,000 women while cervical cancer is 16 out of 100,000 women [3]. This demonstrates that breast cancer affects the greatest number of Indonesian women.

Breast cancer turns a person's life upside down, affecting every aspect of an individual including physical, psychological, spiritual, social, and economic [4]. Research has suggested that being diagnosed with cancer may result in deep emotional problems for both patient and his/her family [5]. Being diagnosed with cancer is the most shocking news a person has to deal with. Cancer may stimulate feelings of phobia, isolation, anger, irritability, confusion, and most commonly anxiety [6]. Living with cancer might be a short or long journey which a person should be well prepared for. Cancer for some people means "that disease" and that disease means dream, hope, life goals lost [7]. 
For several cultures, including Indonesia, breast is essential to women's identity, since it holds an important role in women's feelings with regard to their sexuality, femininity, esthetic appearance, the capability for nurturing, and motherhood. Therefore, being diagnosed with breast cancer does not only threaten life but also their sense of identity as women, that is, the sense of femininity. Breast cancer also produces certain emotional crises for patients and their loved ones. It affects the family functions due to the dramatic change of the distribution of roles and relationships within the family in times of cancer illness [8]. The patients can no longer normally exercise their feminine roles and it affects their identity.

The role of Islamic teaching on psychological aspects is rarely documented, resulting in little information in the literature. At present, much empirical evidence has claimed that religious practice based on Islamic philosophy can enhance psychological wellbeing in patients with breast cancer [9], [10], [11]. Nursing care team is one of the significant elements in caring for the breast cancer patients, as the nurses spend more time with the patients throughout the phases of breast cancer diagnosis and treatment. Use of religious practice on Islamic philosophy will offer a powerful spiritual assistance to cancer patients. Thus, this study aimed to explore the psychological experience after applying Islamic-based practice therapy on women with breast cancer receiving chemotherapy, as perceived by patients. Specifically, the study was to explore the experience of psychological alteration among patients with advanced breast cancer.

\section{Methods}

\section{Study design}

This qualitative study was done with the purpose of exploring the Indonesian females with breast cancer considering psychological experience of using Islamic-based practice therapy.

\section{Sample and settings}

Purposive sampling technique was employed in acquiring informants. Indonesian Muslim women with breast cancer who were receiving chemotherapy treatment and able to speak and understand Bahasa Indonesia were the criteria that have been used in looking for the informants. Researchers have called the potential informants to check their eligibility in participating in this study. A total of 15 Indonesian Muslim cancer patients have joined this study. The interviews were orchestrated in the chemotherapy unit after the chemotherapy session.

\section{Data collection}

The data were gathered by means of semistructured interviews. The in-depth interviews guides used were developed derived from previous literature and researchers' personal experience. First, several common questions were proposed to initiate the interview, for instance: "Please explain how you feel about psychological problems during chemotherapy treatment." The trend of the interviews was derived from the participants' responses. Afterward, the same questions about the patients' psychological experiences after using Islamic religious therapy by the nurses during nursing care treatment were asked. Each interview could last from 45 to $60 \mathrm{~min}$.

\section{Data analysis}

All interviews were tape-recorded and later transcribed verbatim. The interviews were conducted in Indonesian and translated into English by a professional translator. All translated interview transcripts were double-checked by local researchers. A content analysis approach was implemented for data analysis. In accordance with the content analysis process, first, each interview was read carefully for several times to gain a universal and primary comprehension, and the crucial statements were highlighted (to recognize the initial codes or meaning units that occur in the interview text about the participants' psychological experience) in the next stage, these similar meaning units were extracted for clarity of the meanings and categorized in the formation of themes and subthemes. Data analysis was performed in a constant and concurrent way along with the data collection. The data collection procedure was carried on until data saturation, when adding further data resulted in no new information and the supplementary cumulated data were redundant. Finally, the main themes were obtained.

To ensure rigor of the study, validity and reliability of the study were inspected using the Guba and Lincoln's evaluative criteria. To construct credibility, the researchers had adequate cooperation and interaction with the participants. The researchers inspected the dependability of the data through implementing activities such as consulting the supervisor and experts to assess the material.

\section{Ethical clearance}

Ethical approval was granted by Faculty Medicine, Universitas Padjadjaran, Bandung, Indonesia (No. 513/UN6.C10PN/2017). Informants were given explanation on purpose of study and informed consent was taken before data collection. 


\section{Results}

Psychological symptoms had been predominant among patients with advanced breast cancer. During general observation at first contact with patients, they looked sad, depressed, worried, anxious, seeking for answers, dependent on others, tired, and exhausted. Four themes emerged from the interview. The details of themes are as follows:

\section{Theme 1: Self-blaming}

In this study, the participant was blaming herself and presented with negative emotion and feelings related to religion and belief. She said "I am not a good person, I was often late at the time of prayer, so, I committed mistakes and more sins. Probably this is a test from God."

Therefore, self-blaming by the participants came from the negative feeling she felt as a not good person.

\section{Theme 2: Feeling sad}

The factors that make a patient sad are divided into three categories, such as being sad due to costs, being sad due to her illness, and being sad due to not being able to perform her maternal role. For instance, sadness due to cost is related to financial difficulties, not having much money, more debt, and high costs. The participant said "I have financial difficulties, because I don't have much money to go to the hospital frequently. So, now I have more debt." Sad from her disease, the participant said that "the disease is only my own, only I alone got this illness in my village, more and more ill." Moreover, participants experienced hardship in taking part in the maternal responsibility, for instance taking care for her children. Participant said "I am worried about my sons. He is still young." This dysfunction in mother duty is described as an emotional disorder encountered by women.

\section{Theme 3: Feeling fear and uncertainty}

Fear and uncertainty were obvious within all participants. The participant said "I try to hide my fear in front of my husband and my children, nothing clear ..." "Will I live to see my children grow up, cancer took everything from me." Another patient said "It is too early to leave my family; still, I have a lot of things to do .... I cannot close my eyes, afraid I cannot open them again and see my children."

\section{Theme 4: Living in a new body}

In elaborating their ongoing experience with breast cancer, every participant agrees that they live in a new body. The participant said "my body changed after mastectomy, I avoid standing in front of the mirror .... I miss my old body before the illness." Another participant said "I have long black hair, after chemotherapy all my hair is gone .... I tore my entire photo, my hair will never return the same as before." Last participant said "I look different now with pale skin, no hair ...... it is not me, it is not me ...."

Further analysis was carried out to explore the influence of Islamic philosophy approach (prayer and dhikr meditation) on the patients. The following themes were derived:

\section{Theme 1: Closer to god}

After practice of prayer and dhikr meditation, almost all patients feel close to God, for example, the patient said "We feel close and we feel that Allah is so close and hear my prayer" another patient said "I totally surrender my life to God, and accept my destiny depending on God choice."

\section{Theme 2: Peaceful mind}

Most patients reach the peaceful mind throughout their journey in fighting the cancer with chemotherapy and keeping psychological wellbeing. One of the patients said "After practicing prayer and dhikr meditation, I feel peace, calm, and comfortable, there is no feeling of anxiety" another patient said "I can feel that my mind and soul go in peace together." The third patient said "When a doctor diagnosed me with cancer I felt angry and hopeless, but now with practice of prayer and dhikr meditation all the time, I feel peace."

\section{Theme 3: Inner strength}

Noticing her inner strength is improving after applying prayer and dhikr meditation by the following quotation "I feel more healthy and confident after prayer and dhikr meditation and believe I will recover soon." Another patient said "I feel enthusiastic to enjoy my life now"

\section{Discussion}

Dealing with patients diagnosed with advanced breast cancer and being on chemotherapy treatment will have a huge impact on the patient's psychological aspect. Nowadays, chemotherapy is still the first and most common option in treating cancer patients. Chemotherapy is usually associated with many adverse effects on the physical and emotional health of the patients. Physically, patients always complain of 
nausea, vomiting, dizziness, and change in taste; while emotionally, patients feel anger and in denial [12]. All of these negative feelings are normal to be felt in this critical situation. Some studies reported that religious practice in Islam could impact to enhance the mental health [13] and reduce the level of anxiety [14]. Muslim patients with cancer relied on spiritual and religious sources to provide comfort, coping, and meaning in their experience [15], [16], [17]. Patients living with cancer considered their belief in God as a central source of their power [18]. This source supported their inner strength, which was necessary to fight death anxiety. In the 2017 study by Ghahari et al. [19], breast cancer survivors used spiritual/religious resources to solve personal and interpersonal problems that enhanced their coping responses. Both were practicing prayer and religious advice, such as reciting verses from the Qur'an, which played a paramount role in alleviating patients' suffering and promoting a sense of contentment and self-confidence.

In addition, Islamic philosophy provides holistic views in care including psychological well-being which can be practiced in nursing clinical settings. Islamic philosophy will guide the nurse to enhance psychological well-being among women with advanced breast cancer. Interventions based on Islamic philosophy have recently been introduced in clinical settings such as critical unit, hemodialysis, oncology ward, palliative, and community nursing. The benefit has been proved directly on the patients by helping them to accomplish the spiritual well-being and enhanced their psychological wellbeing by promoting self-preservation on psychological adaptation [20], [21].

To apply Islamic philosophy on patients, nurses should be well versed on the method to apply. Nurses should provide ample time and provide space for patients to practice their religious rituals, for example, prayer time before chemotherapy sessions which might take hours. Muslims patients or families should be allowed to recite or listen to the holy Qur'an as a type of meditation or mindfulness that will enhance positivity on the patient's psychological wellbeing [22]. In addition, Islamic philosophy approach is helping the patient to achieve psychological well-being by making them feel closer to God, has a good inner strength and peaceful mind in dealing with their day-to-day conditions. Among Muslim society, belief in God could help them if having problems in their life or sick. They believe that they would touch the Allah, in turn, could help them to strengthen their soul, body, and mind [23], as well as produced a state of calmness and lead to psychological equilibrium, serenity, and harmony.

Limitation was discovered in the study, where the informant cannot be considered as representative of the population of Indonesian Muslim with advanced breast cancer, because the participants in this study were only women who were requested and were willing to discuss their experiences.
To sum up, cancer patients are a fragile group that requires specialized and sensitive care from health-care providers. The patient's physical, spiritual, and psychosocial needs should be addressed in a proper way so that their dignity and well-being can be maintained. Health-care providers should have knowledge on Islamic philosophy and can guide in dealing with Muslim patients. Indirectly, this will assist patients to practice their religion and enhance their psychological domain.

\section{Conclusion}

Overall, in the view of breast cancer patients, the psychological experience of using the Islamicbased Practice Therapy could change to positive responses by making them feel closer to God, having good inner strength, and peaceful mind in dealing with their day-to-day conditions. So, understanding the patient's experience will assist the nurses to promote professional abilities and improve nursing care delivery related to different cultural backgrounds and spiritual dimensions of Muslims patients.

In conclusion, the psychological experience of breast cancer patients who was adopted Islamic-based Practice Therapy, showed a positive impact on their self by helping them feel closer to God, having good inner strength, and having a tranquil mind in dealing with their daily conditions. Understanding of Muslim patient's experience will assist the nurse to provide a better holistic care by imbued their faith practice with the various cultural origins and spiritual dimensions influence.

\section{References}

1. World Health Organization. IndonesiaGlobal Cancer Observatory. Geneva: World Health Organization; 2019. Available from: https:/gco.iarc.fr/today/data/factsheets/ populations/360-indonesia-fact-sheets.pdf. [Last accessed on 2021 Mar 30].

2. Komariah M, Hatthakit U, Boonyoung N. Impact of Islam-based caring intervention on spiritual well-being in muslim women with breast cancer undergoing chemotherapy. Religions. 2020;11:361. https://doi.org/10.3390/rel11070361

3. Sander MA. Profil penderita kanker payudara stadium lanjut baik lokal maupun metastasis jauh di rsup hasan sadikin bandung. Farmasains. 2011;1(2):1168. https://doi.org/10.22219/far. v1i2.1168

4. Hinkle JL, Cheever KH. Brunner and Suddarth's Textbook of Medical-surgical Nursing. Toronto, Canada: Wolters Kluwer India Pvt Ltd.; 2018.

5. Krauel K, Simon A, Krause-Hebecker N, Czimbalmos A, Bottomley A, Flechtner $\mathrm{H}$. When a parent has cancer: 
Challenges to patients, their families and health providers. Expert Rev Pharmacoecon Outcomes Res. 2012;12:795-808. https://doi.org/10.1586/erp.12.62

PMid:23252360

6. Pitman A, Suleman S, Hyde N, Hodgkiss A. Depression and anxiety in patients with cancer. BMJ. 2018;361:k1415. https:// doi.org/10.1136/bmj.k1415

PMid:29695476

7. Nizamli F, Anoosheh M, Mohammadi E. Experiences of Syrian women with breast cancer regarding chemotherapy: A qualitative study. Nurs Health Sci. 2011;13(4):481-7. https:// doi.org/10.1111/j.1442-2018.2011.00644.x PMid:22039884

8. Cebeci F, Yangın HB, Tekeli A. Life experiences of women with breast cancer in south western Turkey: A qualitative study. Eur J Oncol Nurs. 2012;16(4):406-12. https://doi.org/10.1016/j. ejon.2011.09.003

PMid:22000551

9. Jafari N, Farajzadegan Z, Zamani A, Bahrami F, Emami H, Loghmani $A$, et al. Spiritual therapy to improve the spiritual well-being of Iranian women with breast cancer: A randomized controlled trial. Evid Based Complement Altern Med. 2013;2013:353262. https://doi.org/10.1155/2013/353262 PMid:24023572

10. Hosseini L, Kashani FL, Akbari S, Akbari ME, Mehr SS. The islamic perspective of spiritual intervention effectiveness on biopsychological health displayed by gene expression in breast cancer patients. Iran J Cancer Prev. 2016;9:e6360. https://doi. org/10.17795/ijcp-6360

PMid:27482335

11. Fallah R, Golzari M, Dastani M, Akbari ME. Integrating spirituality into a group psychotherapy program for women surviving from breast cancer. Iran J Cancer Prev. 2011;4(3):141-7. PMid:26328054

12. Sajjadi M, Rassouli M, Abbaszadeh A, Brant J, Majd HA Lived experiences of "illness uncertainty" of Iranian cancer patients: A phenomenological hermeneutic study. Cancer Nurs. 2016;39(4):E1-9.

PMid:26098402

13. Ijaz S, Khalily MT, Ahmad I. Mindfulness in Salah prayer and its association with mental health. J Relig Health. 2017;56(6):2297307. https://doi.org/10.1007/s10943-017-0413-1 PMid:28502025

14. Dehghani MK, Dehghani H, Zarezadeh A, Bs NZ. The effect of prayer on level of anxiety in mothers of children with cancer. Iran J Pediatr Hematol Oncol. 2012;2:78-83.
15. Memaryan N, Ghaempanah Z, Saeedi MM, Aryankhesal A, Ansarinejad N, Seddigh R. Content of spiritual counselling for cancer patients undergoing chemotherapy in Iran: A qualitative content analysis. Asian Pac J Cancer Prev. 2017;18(1):1791. https://doi.org/10.22034/APJCP.2017.18.7.1791

PMid:28749107

16. Sajjad S, Ali A, Gul RB, Mateen A, Rozi S. The effect of individualized patient education, along with emotional support, on the quality of life of breast cancer patients-A pilot study. Eur J Oncol Nurs. 2016;21:75-82. https://doi.org/10.1016/j. ejon.2016.01.006

PMid:26952681

17. Rahmani S, Talepasand S. The effect of group mindfulness based stress reduction program and conscious yoga on the fatigue severity and global and specific life quality in women with breast cancer. Med J Islam Repub Iran. 2015;29:175-5. PMid:26034728

18. Rassouli M, Zamanzadeh V, Ghahramanian A, Abbaszadeh A, Alavi-Majd $\mathrm{H}$, Nikanfar A. Experiences of patients with cancer and their nurses on the conditions of spiritual care and spiritual interventions in oncology units. Iran J Nurs Midwifery Res. 2015;20(1):25.

PMid:25709687

19. Ghahari S, Fallah R, Rad MM, Farrokhi N, Bolhari J, Mousavi M, et al. Effect of cognitive-behavioral therapy and spiritualreligious intervention on improving coping responses and quality of life among women surviving from breast cancer. Bali Med J. 2017;6:409.

20. Mardiyono M, Songwathana P, Petpichetchian W. Spirituality intervention and outcomes: Corner stone of holistic nursing practice. Nurse Med J Nurs. 2011;1:117-27.

21. Kwan CW, Chan CW, Choi KC. The effectiveness of a nurseled short term life review intervention in enhancing the spiritual and psychological well-being of people receiving palliative care: A mixed method study. Int J Nurs Stud. 2019;91:134-43. https:// doi.org/10.1016/j.jinurstu.2018.12.007

PMid:30690289

22. Aslami E, Alipour A, Najib FS, et al. A comparative study of mindfulness efficiency based on islamic-spiritual schemes and group cognitive behavioral therapy on reduction of anxiety and depression in pregnant women. Int J Community Based Nurs Midwifery. 2017;5(2):144-52.

PMid:28409168

23. Saniotis A. Understanding mind/body medicine from muslim religious practices of salat and Dhikr. J Relig Health. 2018;57(3):849-57. https://doi.org/10.1007/s10943-014-9992-2 PMid:25613191 